\title{
Cabinet Governance and Political Stability in English Urban Councils
}

\section{Stephen Greasley}

The University of East Anglia

Norwich, UK

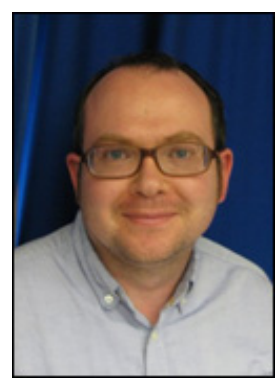

\begin{abstract}
Policy-makers have long been concerned with the quality of local political leadership and have often resorted to institutional reform to try to improve political leadership. This paper looks at a specific and neglected facet of the political management reforms that have been implemented in English local government over the last decade: the tenure and turnover of cabinet members. The tenure of top politicians may be an important influence on the performance of local government particularly when political management is designed to favour individualised leadership. On the one hand, excessively short tenures for top politicians may damage the ability of governments to develop strategic plans and ensure they are implemented while on the other hand the risk of loss of office is central to political accountability and excessively long tenures may be indicative of an insulated and unresponsive elite. While some research attention has been paid to the tenures of leaders of councils in England there is little systematic information about the tenure of cabinet members. This paper discusses the relevance of cabinet stability and provides an overview of recent experience in England.
\end{abstract}




\section{Introduction ${ }^{1}$}

In 2000 the UK parliament passed an Act that was designed to strengthen the political leadership of English local governments. It aimed to make local leadership more efficient, transparent and accountable by establishing small executive cabinets which would be responsible for the day to day decision-making of local authorities. The concerns about local political leadership were not limited to England. In the early 2000s a number of European countries were reforming local political leadership or considering it (Borraz and John, 2004) and similar issues have been discussed in this journal in relation to South African municipalities (de Vissier, 2010). This paper uses the English reforms to explore an important aspect of political systems: the stability of political leadership.

The research that has been conducted on the effects of the English reforms has focused largely on the role of the leaders of councils (for example Greasley and Stoker, 2008; Lowndes and Leach, 2004). This is entirely appropriate but it has downplayed the importance of the other members of a council's cabinet (for an exception see Bochel and Bochel, 2010). Consequently, we currently know very little about the tenure and turnover of cabinet members and certainly less than is known about the leaders of councils (Boyne et al. 2010). This is an important issue, cabinet members are expected to become expert and lead strategy development in their portfolios and at the same time they are accountable for the council's performance in the areas that they cover. The first of these expectations would seem to require some stability of tenure to allow cabinet members to gain experience of their portfolios, develop political leadership skills and see projects through to completion. However, accountability requires that poor political performance should sometime lead to the removal of a cabinet member. The pattern of tenures of cabinet members will therefore partly reflect the trade off between political accountability and political capacity, however there are a number of other factors that may influence the survival of local cabinet members and can thus muddy the issue.

This paper explores cabinet instability in the context of local political cabinets in England. It starts with a discussion of the history of political management reform in England covering its goals, its implementation and the debates over some of its consequences. The next section then discusses the literature that has developed recently on cabinet and portfolio holder stability at the national level. The final section of the

\footnotetext{
1 The collection of the data used in this paper was funded by the ESRC, RES-061-25-0244.
} 
paper presents data on the relationship between political stability, cabinet change and the length of tenure of local portfolio-holders drawn from an ESRC research project.

\section{Reforming Local Political Management}

Good governance is the goal of reformers in many political systems and institutional redesign is often a favoured way of achieving reform. Institutional redesign is appealing because in theory it promises a lasting effect and, once completed, no further interventions are required. There are reasons to doubt this theory; institutions are much more complex than is implied by the reformers' story. Few deny that changing formal structures has an effect on organisations but organisations also exist through the beliefs and actions of their members, the tacit rules of institutions cannot be precisely engineered by legislation and they have the potential to subvert the intentions of reformers (March and Olsen 1984; Lowndes, 2005). In short, institutions are path dependent, their histories limit their future trajectories and these in turn limit the predictability of the effects of reforms (Pierson, 2000). Once it is also recognised that contextual factors can strongly influence the way that abstract models operate after they are implemented in real organisations, there are then reasons to doubt that the plans of reformers will be fully achieved (Lowndes and Leach, 2004).

When it comes to English local democracy, institutional reform has often been the weapon of choice for national policymakers. Over the last half century there have been institutional re-organisations of various flavours and there is little sign that the pace will let up. The current coalition government's Localism Bill 2011 proposes that council leaders in the twelve largest English cities outside London will become 'shadow mayors' and referendums will be held on whether they should become directly-elected mayors. ${ }^{2}$ This represents a continuation of earlier and substantially unsuccessful efforts to introduce mayoral governance to English cities. At the same time the 2011 Bill loosens the requirement that all the larger councils must operate with a political executive cabinet distinct from the council as a whole.

This paper focuses on the operation of political cabinets introduced by the Local Government Act 2000. These new structures were an important element of New Labour's modernisation agenda with respect to local government (Bochel and Bochel, 2010). The objectives of the 2000 Act were to create visible and effective leadership; to enhance

${ }^{2}$ At the time of writing the Bill is being considered by the House of Lords

$<$ http://services.parliament.uk/bills/2010-11/localism.html> (accessed 18 July 2011). 
democratic legitimacy; and to provide checks and balances in the construction of the new system (Gains et al. 2009 summarise the findings of an extensive evaluation project). These objectives reflected a concern that the operation of local politics in England was flawed (Pratchett, 2004) often failing to address issues of community concern or failing to ensure the quality of services. The focus on strengthening leadership through institutional reforms produced some criticisms, for example that its effects had been limited and diverse (Lowndes and Leach, 2004). Away from the English context a general note of caution about 'being bitten by the leadership bug' has recently been sounded by (Grant et al. 2011, 66) who argued that the focus on leadership may be a distraction from the more fundamental problems faced by local government and that there may be unintended consequences resulting from changes to models of leadership.

The most radical of the reform options was for a council to have a directly-elected mayor. Traditionally, leaders have been selected by councillors from the council body but the directly-elected mayors were to be placed in office by the electorate as a whole, loosening the role of political parties in leader selection. Once elected, the mayor then selects a cabinet drawn from the council. Very few (initially ten) areas opted for a directly-elected mayor, with the vast majority of councils selecting a less radical reform called the leader-cabinet system (Gains et al. 2005). With this option there were three features that marked a formal and significant change from the previous committee system. The first feature was the selection of a small group of executive members from the main body of the councillors to form a cabinet. These executive cabinets were given responsibility for implementing policy across the range of council functions ${ }^{3}$ within a framework adopted by the council as a whole. They were also expected to play a key role in developing policy proposals, budget making and prioritisation. Under the previous system there was no legal differentiation between 'executive' and 'non-executive' councillors but even before the introduction of executive structures researchers were able to identify an increasing distinction between lead and backbench councillors (Elcock cited in Bochel and Bochel, 2004, 39). The new system formalised and to an extent strengthened that distinction. The second feature was that partisan membership of the new cabinets was not required to be proportional to the party seat share on the council as a whole. After the reform, where a single party holds a majority on a council the majority group can, and usually does, establish a single party executive cabinet. The third feature was the potential to give individual cabinet members delegated power to make executive

${ }^{3}$ With the exception of regulatory functions such as planning and licensing. 
decisions in their areas of responsibility. This strengthening of leadership was accompanied by a range of features designed to ensure executive accountability, for example scrutiny committees, 'call-in' powers and key decision rules (Leach and Copus, 2004).

The initial response to the legislation by councils was marked by a small ' $c$ ' conservatism. The leader-cabinet councils were cautious about giving leaders all the powers allowed in the legislation (Gains et al.2005) but as the system settled down more councils strengthened the position of their leader (Gains et al. 2009). Formal structure was only one influence on the way that cabinets operated and different councils found different ways to make their cabinets work. Some cabinets were dominated by the leader, others allowed individual portfolio holders greater discretion, others were more committed to collectivist decision-making (ELG, 2004; Lowndes and Leach, 2004). The story of the implementation of the Act was of continuing diversity of operation within the legal framework.

Variety of political context is among the most important of the sources of this diversity. The legislation's model of strong and effective leadership may be vulnerable to the operation of the local electoral system and local party systems. On local elections, although there is evidence of a performance-vote link (Boyne et al., 2009) it is undoubtedly true that in England local elections are second order elections - they are often strongly influenced by national factors and if the political control of a council changes it may have little to do with the actions of the local parties or the performance of local incumbents. On the influence of parties, inter and intra party rivalries may, for better or worse, push local political management away from the legislation's goals. Perfectly competent and effective cabinet members may have to leave office for reasons that have little to do with their decisions or management.

The legislation allowed for some variety in implementation but it seems clear that the Government's preference was for a 'strong leadership' model. This model did not necessarily imply leaders monopolising decision-making, but rather their having the tools to select and manage their cabinets (Bochel and Bochel, 2010; Greasley and Stoker, 2008; Greasley and John, 2011). As yet we lack even basic knowledge about how long local cabinet members serve and what sorts of factors influence turnover of executive politicians. The next section will review recent debates about why tenure of national 
cabinet members may be important and argues that similar issues are worth pursuing at local level.

\section{Dynamics of Cabinet Governance}

Where political institutions are designed to produce collectivist decision-making and accountability the rate of turnover of individual politicians may not be too important. Collective structures may be more robust to changes in personnel because responsibility, relevant experience and knowledge is dispersed across a number of individuals. In cabinet systems, however, individual politicians play an important role in the policy process, they are allocated portfolios and are expected to lead the construction of strategy for policy and service development. If there is too much 'churn' in the occupants of cabinet positions then the policy process may be damaged (Huber and MartinezGallardo, 2008).

In research on parliamentary democracy a great deal of attention has been given to the termination of governments but less so to the length of ministerial careers. Recent analysis has however explored the relationship between government termination, cabinet turnover and ministerial tenure (Huber and Martinez-Gallardo, 2008). The analysis of national cabinets has generally approached the question from the assumption that the leader decides who serves, which portfolio each holds and when they will be moved or removed. These powers can help leaders to manage political difficulties and to deliver policy goals (Huber and Martinez-Gallardo, 2008). However, there are problems that are common to all processes of selection: how can a leader know she is getting the right person for a given portfolio? The problem of ministerial talent is that it may not be observable in advance of appointment. The leader will try to develop ways of screening ministerial candidates and the more successful the leader is at this the less likely it is that they will inadvertently appoint a weak minister. A second problem relates to whether a leader can monitor and manage the cabinet. Much of what is involved in the ministerial job is not easy to monitor, many ministerial actions will involve giving informal direction to officials and sending signals to, or making deals, with members of policy communities. Ministers will accumulate specialised knowledge and information giving them an advantage in negotiations with the leader and this will be a problem if ministers have goals that differ from those of the leader, i.e. representing departmental interests at the expense of the common interest of the government (Indridason and Kam, 2008). 
Huber and Martinez-Gallardo (2008) demonstrate that in national parliaments the link between government termination and the termination of individual ministers' jobs is quite weak. Not all ministers leave office when a government ends and many ministers leave office whilst the government remains (2008: 171). Berlinski et al. (2010) in their analysis of the impact of performance on ministerial tenure, find support for the claim that a minister's performance relative to the performance of other ministers is important for explaining when they leave office. This research starts from the assumption that the leader is (formally) empowered to select and remove their cabinet members. Huber and Martinez-Gallardo (2008) discuss the constraints that may be imposed on leaders' discretion by the existence of coalition government or other factors but the general picture is of cabinet members serving at the invitation of the leader.

\section{From National to Local}

The key question is whether the factors that are relevant for explaining patterns of change and stability in national cabinets are relevant to local governments. Just because a local authority has a cabinet structure it does not follow that it will display the same dynamics as national cabinets. The low profile of local government in England is not helpful in identifying the reasons why a cabinet member has left office. It is often not easy to uncover whether a 'resignation' is really a resignation. However, there have been some high profile examples of local cabinet members resigning as a result of failures in the service they oversee. The case that made the national media related to the failings in child protection in Haringey and the resignation of the relevant portfolio holder (along with the leader and the sacking of a member of staff). ${ }^{4}$ Another example from Milton Keynes relates to a failure in a school building project. ${ }^{5}$ However, there are other reasons for cabinet members to leave office, for example to pursue outside interests, or because of personality clashes, or, in one case, a reported involvement with gun-running in the distant past. ${ }^{6}$

Here, I discuss four ways in which national and local politics potentially diverge: the motivations of politicians may be different at the different levels; local council leaders have a smaller pool of politicians from which to select their cabinets especially if they have a small majority; the level of task complexity for local portfolio-holders is lower

$4<$ http://www.communitycare.co.uk/Articles/2008/12/01/110138/baby-p-haringey-leader-and-childrenscabinet-member-resign.htm>

$\frac{\mathrm{c}}{5}<\mathrm{http}$ ///www.miltonkeynes.co.uk/news/local/council_boss_urged_to_resign_1_866019>

$6<$ http://www.telegraph.co.uk/news/politics/conservative/3543467/Tory-councillor-quits-cabinet-afterformer-membership-of-IRA-disclosed.html>. 
than in national government; and, at local level in England the electoral cycle is fixed which breaks the link between an administration collapsing and new elections. One of the key assumptions of most analysis of national cabinet politics is that, for whatever reason, politicians seek and wish to retain executive office (in their conclusion Berlinski et al. 2007 discuss whether this is always the case). Whether or not it is a safe assumption at national level when we move to local politics we are studying a group of individuals who may have careers to attend to outside local government. There are certainly councillors who do not seek cabinet position either because they have a fulltime job, a family or because they wish to enjoy their retirement. Nevertheless, even taking into account these factors, the appeal of holding or not holding cabinet position is likely to still be related to, for example, how much political conflict there is or how well the services for which a cabinet member is responsible are performing. That is to say, length of cabinet tenure will have some relation to politics and performance and so can still play a role in accountability.

Another significant difference between national and local governments is that the smaller size of local councils gives leaders less freedom to shuffle or remove cabinet members (although this may also be a problem nationally, Dewan and Myatt, 2010). Local leaders have to find their cabinet from a small pool of politicians, the size of which depends on the size of the parties in the administration and the willingness of members to take up cabinet positions. This scarcity may limit the scope for leaders to use selection and removal as tools to manage cabinets.

The third difference is that at national level the size and complexity of government is such that it may be difficult for a leader to 'keep tabs' on the decisions and performance of their cabinet. At the local level this problem is significantly mitigated. Local government is less complex than national politics and over the last decade the administrative centres of local government have been strengthened by a plethora of performance monitoring structures and the increasingly important role of the chief executive and corporate directors in the administrative structure. These changes allow leaders access to the type of information which may be useful in managing political performance. Having said all that, the monitoring problem that leaders face is not trivial. Local government in England is large compared to many systems, it is responsible for the delivery of a range of complex services and portfolio holders typically do have 'their own' officials who provide them with information and support. 
Finally, a fourth structural difference between local and national is the relationship between the collapse of political administrations and the timing of elections. Elections in local authorities operate on a fixed timetable, there is no scope for local leaders to call an election, so if the cabinet loses the confidence of the council then a new administration has to be formed from the existing body of politicians. The electoral system of English local government adds a further complication because in a large proportion of councils the elections occur 'by thirds'. In these authorities, the council as a whole never stands for election ${ }^{7}$ instead a third of council seats are up for election in a given year, with one year out of four left 'fallow' when no election occurs. The implications of this are that the balance of the council can change more frequently where elections occur by thirds compared with where all out elections are held, and different politicians within a cabinet will be due for re-election at different times.

In summary, a fundamental concern with the application of the research on ministerial careers to local cabinets is that the nature of local politics is simply different, perhaps less competitive, or less calculating or less ideological than national politics. The approach of this paper is to assume that local cabinets are political institutions like other political institutions and are subject to fundamentally similar pressures. There is some evidence that indirectly supports this position. Bochel and Bochel's (2010: 733-4) paper discusses the way that council leaders in a variety of authorities think about the process of selecting cabinet members and allocating portfolios. Leaders are well aware of the importance of these powers but as Bochel and Bochel point out in the context of multiparty coalition the leader's discretion is constrained with respect to cabinet selection and portfolio allocation. Greasley and John (2011) presents some evidence that where leaders have powers related to the management of cabinets (selection and portfolio allocation) the relative performance of their council as judged by citizens is improved. This finding is consistent with, although hardly proof of, the proposition that selection, management and removal of executive members plays an important role in achieving political accountability. However, there is remarkably little direct evidence on the careers of local cabinet members. The next section provides an initial exploration of cabinet stability. It starts with an overview of urban councils in England, exploring the relationship between elections, leader change and cabinet stability over a five year period. The paper then focuses on the experience of the London Boroughs over a single election cycle.

\footnotetext{
${ }^{7}$ With the exception of immediately after a periodic electoral review and a redrawing of boundaries.
} 


\section{Cabinet Stability: An Initial Exploration}

This section explores how frequently politicians leave local political cabinets. The aim is to present an overview of the level of stability in local executive political leadership and to start to understand how much of it is driven by factors such as electoral change. If cabinet membership only really changes with elections or change in political control then that would be strong evidence that leaders are not using their powers to remove poor performing portfolio holders. In that case, researchers would need only to understand the aggregate measures of political instability: electoral change and change in administration. This section shows that while these aggregate factors exercise an important influence on executive member turnover they are by no means the whole story.

The advantages of studying local governments are that there are multiple cases to analyse and that many factors are held constant. The downside is that the required information may not be available and where it is available it is often dispersed and requires significant work bringing it together. The data for this paper was taken from the official papers of local councils accessed via their websites. For each council year (normally running from May to April) the names of cabinet members and the leader at the start of the year were recorded. In many cases these names were reported in the minutes of the Annual Meeting of the council, failing that a second source of cabinet membership is the agenda of cabinet meetings which often lists the names of cabinet members. If the names of cabinet members could not be found using either of those methods the membership of a cabinet was constructed using the minutes of cabinet meetings. Where this final source was used, names from the minutes of the first meeting of the council year (typically in May) were checked against the minutes of at least the two subsequent cabinet meetings.

The data relates to the English urban local authorities namely the metropolitan boroughs, the London boroughs and the unitary authorities. ${ }^{8}$ It includes information on 114 councils and cabinet memberships from 2004/05 to 2009/10. The primary unit of analysis in the data is the 'council-year'. In this paper I am interested in stability and change, consequently the first year of observations for any council drops out - nothing can be said about the change in cabinet in 2004/05 because the information on cabinet membership in 2003/04 is not included in the data. The focus is on members leaving the cabinet (from this point forward referred to as 'leavers'), hence the measure of change for 'council A in year 2' is the number of politicians' names in a cabinet at the start of 'year 1' that do not

\footnotetext{
${ }^{8}$ It does not include the 're-organised' unitary authorities that came into being in 2009.
} 
feature in the cabinet at the start of 'year 2'. So, for example, if the 2006/07 cabinet of Barking and Dagenham is missing 2 names that were in the 2005/06 cabinet, then for the council-year 'Barking and Dagenham 2006/07' the value of 'leavers' would be 2. For some councils, there are gaps in data in the earlier years of the time period, in total there are 511 'council-year' observations in the dataset for which the change data discussed in this section is available.

On average 1.88 members left a local cabinet in a council-year, the median number of leavers in a council-year was 1 and in just under 31 per cent of the council-years there were no leavers. The maximum number of changes that can occur is 10 (the maximum size of a cabinet) but some cabinets have fewer than 10 members, to account for this variation in cabinet size the percentage of a previous year's cabinet members that had left by the subsequent year was calculated. ${ }^{9}$ On average just under 21 per cent of members were leavers in any given council-year (see Table 1 for a summary). This average is inflated by the cases where a council as a whole changes political hands but not as much as might be expected. This is because, firstly there are not that many examples of change of political control in the data (45 cases) and secondly, changes in political control frequently involve a move from 'no overall control' to a single party majority (or vice versa), in such cases it is not unusual for some of the sitting cabinet members to survive in office. Considering only those instances where there had been no change in the political control (466 cases) an average of 17 per cent of previous year's cabinet members were leavers, but where there had been a political change an average of 58 per cent were leavers.

The direct effect of electoral factors can be removed from the analysis by looking only at those cabinet-years where no election was held. There were 302 observations where there was no election, and on average in these cases 13 per cent of cabinet members left office (compared to 31 per cent where there was an election). There were also still a few examples where the whole of a cabinet left office even when there had not been an election, these cases are likely to represent the collapse of multi-party coalitions or minority administrations and their replacement by rivals from other parties.

In one of the high profile examples of local cabinet resignation discussed earlier, both a cabinet member and the leader resigned. In this data the leader changed in 93 of the

\footnotetext{
${ }^{9}$ Percentages are also problematic here, because the denominator is so small they are very sensitive to small
} changes. 
council-years (approximately 18 per cent), and this was quite strongly correlated with the percentage of cabinet leavers in a council year (Kendall's tau $b=.36 ; p=.000$ ). In cases of change in political control we would expect the cabinet and its leader to go down together although the relationship is more complicated in transitions from or to no overall control. Looking only at those cases where there had been no change in political control, although the correlation is not as strong, there is still evidence of a moderate relationship between change in leader and percentage of cabinet leavers (Kendall's tau $b=.25$; $\mathrm{p} .=.000)^{10}$.

Table 1. Average percentage of cabinet leavers per council-year, by political context

\begin{tabular}{|rr|}
\hline & $\begin{array}{r}\text { Average } \% \\
\text { leavers }\end{array}$ \\
\hline Overall & $21 \%$ \\
\hline Change political control & $58 \%$ \\
No change & $17 \%$ \\
\hline Election year & $31 \%$ \\
No election year & $13 \%$ \\
\hline Leader change & $48 \%$ \\
No leader change & $12 \%$ \\
\hline
\end{tabular}

This initial look at cabinet member tenure demonstrates that political change, election years and leader change are quite strongly associated with an increase in the average proportion of leavers. Having said that, there does also seem to be a certain amount of change that is not associated with those factors. As Figure 1 shows, the number of leavers per council-year does tend to be lower when there is no election and the distribution for non-election years is more skew, with a large minority of cabinets losing no members (left panel). However, there remains a fairly substantial level of change in evidence.

It is difficult however to understand from this analysis the substantive importance of this instability for councils. For example, the changes that do occur may have been concentrated in a few councils which had considerably greater instability than others or they may have been spread evenly across councils with many experiencing a relatively low level of change. The next subsection looks at this question by focusing only on the London Boroughs over a single electoral cycle.

\footnotetext{
${ }^{10}$ There is little change if the no overall control councils are also taken out.
} 


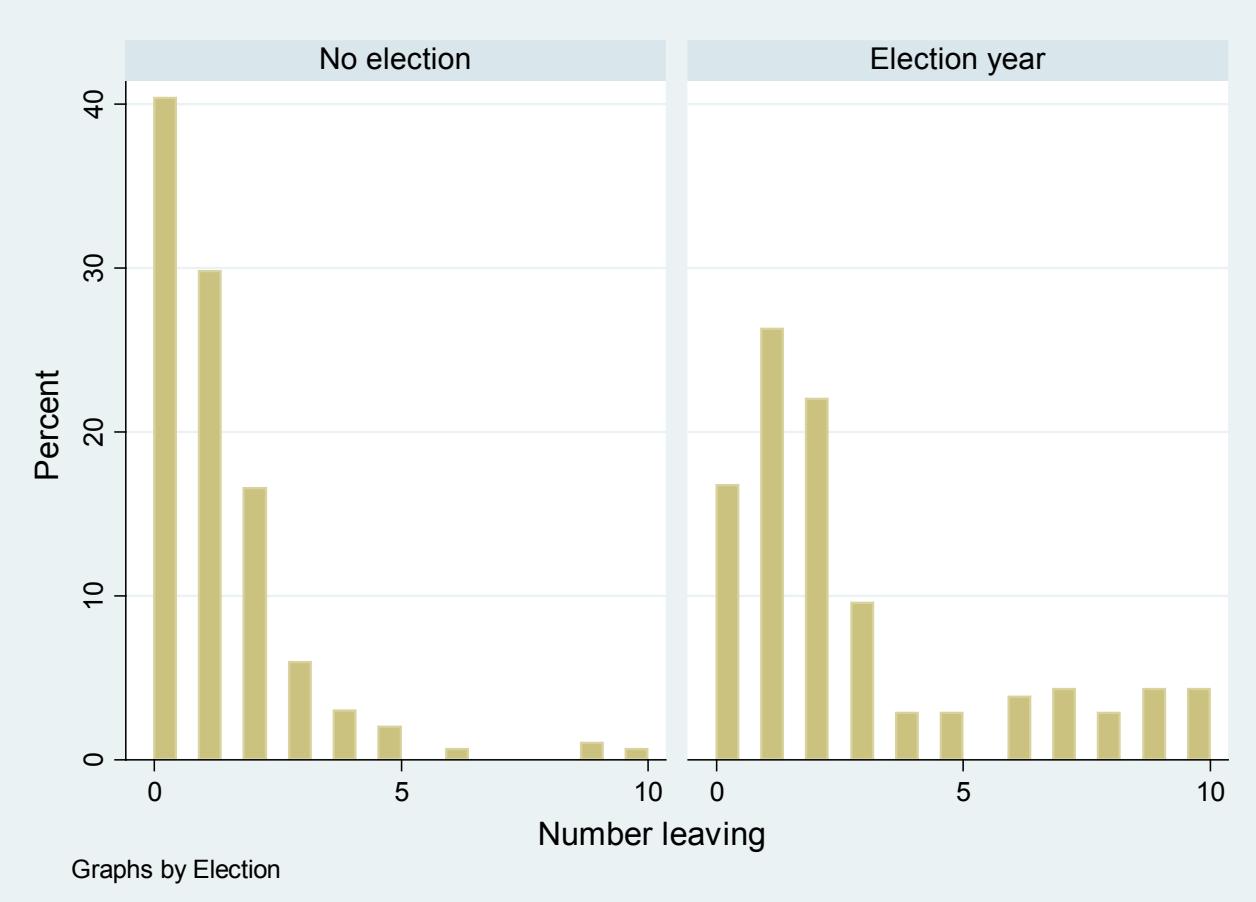

Figure 1. Number of cabinet-leavers, election year compared to no election year

\section{Cabinet stability in London}

There are thirty-two London Boroughs that govern the capital along with the Mayor of London and the Greater London Authority. On average they serve populations of just over 235,000 people, ranging from the smallest (Kingston-upon-Thames) at 160,000 to the largest (Croydon) at nearly 337,000. London Boroughs share the same election timetable and they have all-out elections every four years so there is an extended period of operation without an election looming. This makes them a useful setting to look at variation in cabinet stability across time. The data in this subsection starts with the elections of May 2006, and then measures changes in cabinet membership until the start of the final year in the electoral cycle in May 2009. This means that there is information on three rounds of possible changes (2006/07 - 2007/08; 2007/08 - 2008/09; 2008/09 2009/10). As before, if a politician who was in the cabinet at the start of the 2006/07 year was absent from the cabinet at the start of 2007/08 then this is coded as the end of their tenure.

Figure 2 shows how many leavers there were per council over the whole electoral cycle. Only four London Boroughs went through to the start of the final year without a cabinet member leaving: Hillingdon, Lewisham, Newham and Sutton. Figure 2 does suggest that the distribution of leavers across councils was not even and that cabinet instability in 
London over this period was concentrated in a small number of authorities. The highest score was eleven in Tower Hamlets, with Redbridge and Southwark also experiencing a relatively large number of leavers. One implication of this is that, for these councils at least, it seems unlikely that the end of cabinet careers can be satisfactorily explained by personal or idiosyncratic factors, it looks as if there were certain councils that experienced greater instability for whatever reason. Looking at the most unstable Tower Hamlets, Redbridge, Southwark - Southwark had no single party in overall control, Tower Hamlets had a Labour majority and Redbridge had a Conservative majority. Political conflict may be important in these councils, but if it was it was occurring within as well as between parties. A second feature to note is that the three mayoral authorities in London are all clustered towards the left of the figure, they had relatively stable cabinets and this may reflect the strength of position of the mayors in selecting their executive members. ${ }^{11}$

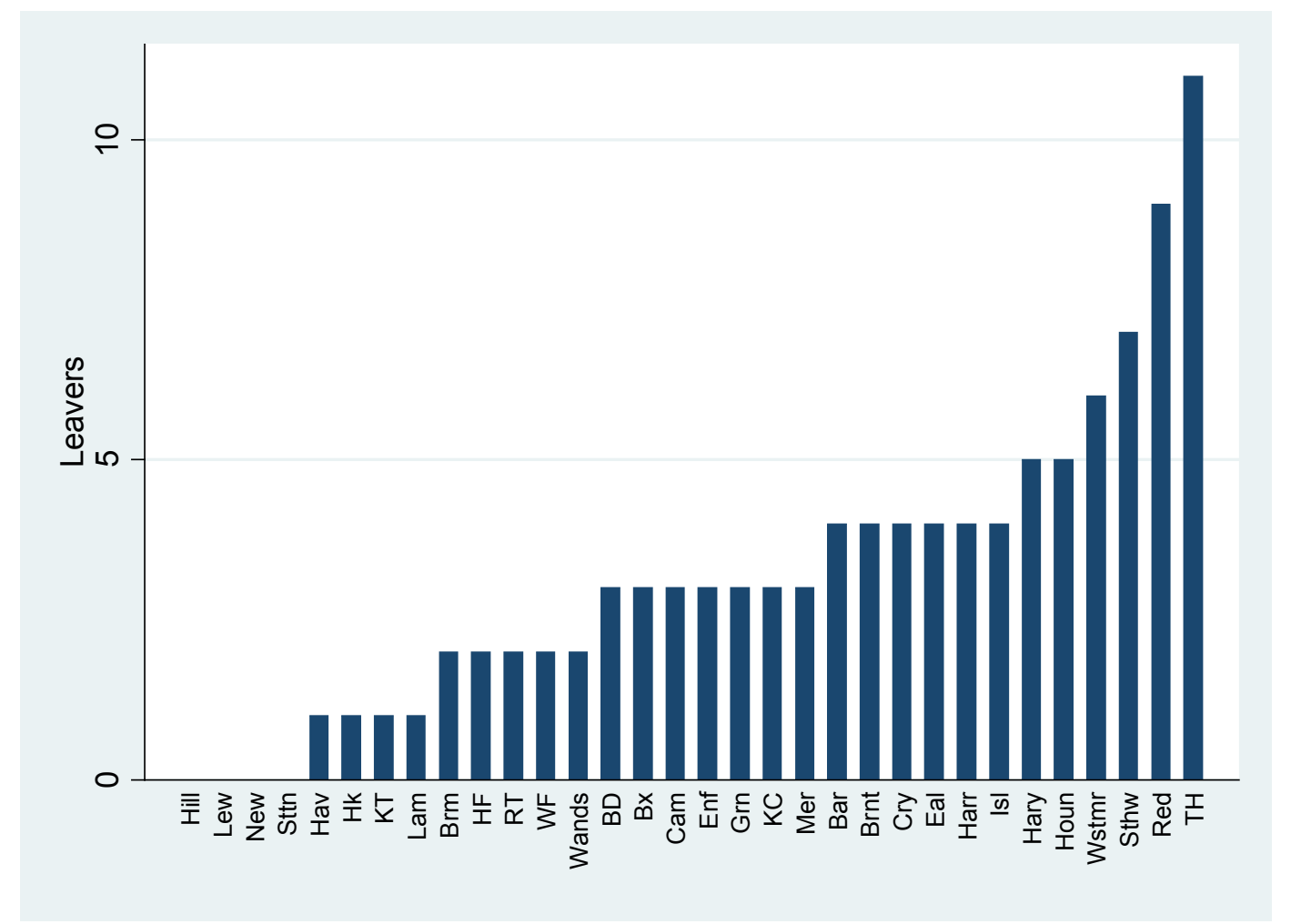

Figure 2: Number of 'cabinet-member terminations' (including leaders) 2006/07 2009/10, London Boroughs ${ }^{12}$

\footnotetext{
11 This does not generalise to all mayoral authorities in England, some of which have experienced considerable instability.

${ }^{12}$ A key to council labels can be found in the appendix at the end of the paper.
} 
The first part of this section showed that there were non-trivial levels of cabinet instability in English city councils even when looking only at council-years which did not experience elections or political change. Although the instability of cabinet membership is related to political change, elections and leader change it is also in part independent of these factors. The second part of this section showed that in London Boroughs between elections the level of instability was not evenly spread, a small group of councils experienced greater churn suggesting that there may be council level variables explaining stability and instability in local cabinets. As yet there is little that can be said about what may be causing instability and what the consequences of it are. This is an important priority for future research.

\section{Conclusions}

Stability of leadership can be crucial for the effective operation of democracy but whether it is good or bad will depend on contextual factors. If government is performing well then excessive churn in leadership positions may damage policy making. It may make strategic decision making difficult and it will give leaders the incentive to pay attention to the short term rather than the long term. On the other hand, where cabinet members hold long tenures this may indicate unresponsiveness and a lack of accountability in the political system. If the performance or policy making in a policy area is poor then changing the politician with direct responsibility for the area is one of the possible responses. The difficulty for democracies is that it is often really difficult to distinguish between these two conditions because sometimes organisational performance may have to dip before it can improve. For example, responsible politicians with an eye on the long term performance of a government may have to take unpopular decisions in the short term, but is it possible to distinguish them from politicians who are unpopular because they are bad at their jobs? The tenure of cabinet members reflects how this balance is being struck. The role of local portfolio holders was arguably very important to the success or failure of the institutional reforms under the Local Government Act 2000 but it has received limited research attention. The analysis here explores an aspect of the variation in the context in which these portfolio holders have had to operate. Some cabinets are populated by members who can be confident that they will be in post for some time in other cabinets the future of its members is less secure. 


\section{References}

Berlinski, S., Dewan, T. and Dowding, K. 2007. 'The Length of Ministerial Tenure in the UK, 1945-1997' British Journal of Political Science 37: 2, pp. 245- 262.

Berlinski, S., Dewan, T. and Dowding, K. 2010. 'The Impact of Individual and Collective Performance on Ministerial Tenure' The Journal of Politics, 72:2, pp.559-71.

Bochel, H. and Bochel, C. 2004. 'Women 'Leaders' in Local Government in the UK' Local Government Studies, 30: 1, pp. 36-50.

Bochel, H. and Bochel, C. 2010. 'Local Political Leadership and the Modernisation of Local Government' Local Government Studies, 36:6, pp. 723-737.

Borraz, O. and John, P. 2004. 'The Transformation of Urban Political Leadership in Western Europe' International Journal of Urban and Regional Research, 28: 1, pp. 107-120.

Boyne, G., James, O., John, P. and Petrovsky, N. 2010. 'Does Political Change Affect Senior Management Turnover? An Empirical Analysis of Top-Tier Local Authorities in England' Public Administration, 88: 1, pp. 136-153.

Boyne, G., James, O., John, P. and Petrovsky, N., 2009. 'Democracy and Government Performance: Holding Incumbents Accountable in English Local Government' The Journal of Politics 71: 4 pp. 1273-1284.

Boyne, G., James, O., John, P. and Petrovsky, N., 2010. 'Does Public Service Performance Affect Top Management Turnover?' JPART, 20, pp. i261-i279.

de Vissier, J. 2010. 'The Political-Administrative Interface in South African Municipalities: Assessing the Quality of Local Democracies' Commonwealth Journal of Local Governance Issue 5.pp. 88-101.

Dewan, T. and Myatt, D. 2010. 'The Declining Talent Pool of Government' American Journal of Political Science, 54: 2 pp. 267-86.

ELG. 2004. Operating the New Council Constitutions in English Local Authorities: A Process Evaluation. London: ODPM.

Gains, F., Greasley, S., John, P. and Stoker, G. 2009. 'The Impact of Political Leadership on Organisational Performance: Evidence from English Urban Government' Local Government Studies 35: 1, pp. 75-94.

Gains, F., John, P. and Stoker, G. 2005. 'Path Dependency and the Reform of English Local Government' Public Administration 83: 1, pp. 25-45.

Grant, B., Dollery, B. and Gow, J. 2011. 'Local Democracy and Local Government Efficiency: The Case of Elected Executives in Australian Local Government' Australian Journal of Political Science 46: 1, pp. 53-69.

Greasley, S. and John, P. 2011. 'Does Political Leadership Have a Performance Payoff? Citizen Satisfaction in the Reform of Subcentral Government in England' Journal of Public Administration: Research and Theory 21:2, pp. 239-256

Greasley, S. and Stoker, G. 2008. 'Mayors and Urban Governance: Developing a Facilitative Leadership Style?' Public Administration Review 68:4 pp. 722-730.

Huber, J. and Martinez-Gallardo, C. 2008. 'Replacing Cabinet Ministers: Patterns of Ministerial Stability in Parliamentary Democracies' American Political Science Review, 102:2, pp. 169-179.

Indridason, I. and Kam, C. 2008. 'Cabinet Reshuffles and Ministerial Drift' British Journal of Political Science 38, pp. 621-656.

Leach, S. and Copus, C. 2004. 'Scrutiny and the Political Party Group in UK Local Government: New Models of Behaviour’ Local Government Studies, 82: 2 pp. 331-354.

Lowndes, V. and Leach, S. 2004. 'Understanding Local Political Leadership: Constitutions, Contexts and Capabilities' Local Government Studies 30: 4, pp. 557-575.

Lowndes, V. 2005. 'Something Old, Something New, Something Borrowed: How Institutions Change (and Stay the Same) in Local Governance' Policy Studies, 26: 3-4, 291-309. 
March, J. and Olsen, J. 1984. 'The New Institutionalism: Organizational Factors in Political Life' The American Political Science Review, 78: 3, pp. 734-749.

Pierson, P. 2000. 'Increasing Returns, Path Dependence, and the Study of Politics' American Political Science Review 94: 2 pp. 251-267.

Pratchett, L. 2004 'Institutions, Politics and People: Making Politics Work' pp. 213-229, in Stoker and Wilson (eds) British Local Government into the $21^{\text {st }}$ Century. Basingstoke: Palgrave MacMillan.

Pratchett, L. 2004. 'Institutions, Politics and People: Making Local Politics Work' pp. 213-229 in Stoker and Wilson (eds) British Local Government into the $21^{\text {st }}$ Century. Basingstoke: Palgrave MacMillan.

Wollmann, H. 2008. 'Reforming Local Leadership and Local Democracy: The Cases of England, Sweden, Germany and France in Comparative Perspective' Local Government Studies, 34: 2, pp. 279-298.

Appendix: Key to labels, Figure 2

\begin{tabular}{llll}
\hline Barking and Dagenham & BD & Kensington and Chelsea & KC \\
\hline Barnet & Bar & Kingston upon Thames & KT \\
\hline Bexley & Bx & Lambeth & Lam \\
\hline Brent & Brnt & Lewisham & Lew \\
\hline Bromley & Brm & Merton & Mer \\
\hline Camden & Cam & Newham & New \\
\hline Croydon & Cry & Redbridge & Red \\
\hline Ealing & Eal & Richmond-upon-Thames & RT \\
\hline Enfield & Enf & Southwark & Sthw \\
\hline Greenwich & Grn & Sutton & Sttn \\
\hline Hackney & Hk & Tower Hamlets & TH \\
\hline Hammersmith and Fulham & HF & Waltham Forest & WF \\
\hline Haringey & Hary & Wandsworth & Wands \\
\hline Harrow & Harr & Westminster & Wstmr \\
\hline Havering & Hav & & \\
\hline Hillingdon & Hill & & \\
\hline Hounslow & Houn & & \\
\hline Islington & Isl & & \\
\hline & & & \\
\hline
\end{tabular}

